\title{
Banka Performanslarının Ölçümünde Risk Bazlı Uzaklık Yönlü Fonksiyon Yaklașımı
}

\section{Özge SEZGiN ALP1 - Adalet HAZAR²}

Makale Gönderim Tarihi: 20.10.2014

Makale Kabul Tarihi: 23.12.2014

\section{Öz}

Bankacılık sektöründe, özellikle son yıllarda artan rekabet ortamı bankaların mevcut kaynakları ile etkin bir șekilde çalıșmalarını zorunlu kılmaktadır. Bu nedenle, bu çalıșmada Türkiye'de faaliyet gösteren ticari bankaların etkinlikleri, temel çıktılar olan krediler ve porfföy yatırımları ile birlikte istenmeyen çıkılar olan kredi riski ve piyasa riskini aynı zamanda değerlendirmeye imkan tanıyan uzaklık yönlü fonksiyon yaklașımı ile ölçülmüștür. Yapılan analizler sonucunda, bankaların değerlendirilmesinde yalnızca olumlu çıkıların kullanılmasının yanılııı olacağı, risk seviyelerini nasıl yönettiklerinin de dikkate alınması gerektiği sonucuna ulașımıștır.

Anahtar Kelimeler: bankacılık, etkinlik, risk, uzaklık yönlü fonksiyon.

\section{RISK BASED DIRECTIONAL DISTANCE FUNCTION APPROACH IN EVALUATING BANK PERFORMANCE}

$1 \quad$ Yrd. Doç Dr. Özge SEZGiN ALP, Bașkent Üniversitesi, Ticari Bilimler Fakültesi Bağlıca Kampüsü Eskișehir Yolu 20. Km Bağlıca 06810 Ankara, e-mail: osezgin@baskent.edu.tr

2 Doç. Dr. Adalet HAZAR, Akademi Eğitim Nenehatun cad.42/4 Gaziosmanpașa, Ankara, email: adalethazar@gmail.com 


\section{ABSTRACT}

In banking sector, especially with the increased competition in recent years, it becomes very important to work efficiently with available resources. Therefore, in this study it is aimed to evaluate the efficiency of Turkish commercial banks with directional distance function approach which allows evaluating the efficiency with main outputs such as portfolio investments and loans together with undesired outputs such as credit risk and market risk. The results show that while evaluating the banks efficiency just taking into account the desired outputs may be misleading and while evaluating how they manage their risk levels is also important. function.

Keywords: banking, efficiency, risk, directional distance

\section{GíRiș}

Finansal piyasalardaki gelișmeler ve liberalleșme ile birlikte bankacllık sektörü son yıllarda özellikle Türkiye gibi gelișmekte olan ülkeler için önem arz etmektedir. Bankacılık sektörünün Türkiye ekonomisi üzerinde etkisi düșünüldüğünde sektörün etkin çalıșıp çalıșmadığının değerlendirilmesine yönelik çalıșmalar yapılması zorunluluk haline gelmiștir. Bu amaçla, Türk bankacılık sisteminde etkinlik ve verimlilik analizleri üzerine birçok çalıșma bulunmaktadır. Türkiye'de bankacılık sektörünün performansının ölçülmesine ilișkin son yıllarda yapılan bazı çalıșmalara Cingi ve Tarım (2000), Ekren ve Emiral (2002), Çatalbaș ve Atan (2005), Önal ve Sevimeser (2006), Özcan (2006), Özgür ve Eleren (2006), Șen (2006), Seyrek ve Ata (2010) örnek verilebilir.

Cingi ve Tarım (2000) çalıșmalarında Türk bankacılık sisteminin 1989-1996 yıllarına ait verileriyle VZA-Malmquist toplam etkinlik endeksi uygulaması ile bankaların etkinliklerini ölçmüșlerdir. Aynı șekilde Ekren ve Emiral (2002) çalıșmalarında bankaların teknik etkinlik değerlerini VZA-Malmquist toplam etkinlik endeksi yöntemleri ile değerlendirmișlerdir.

Çatalbaș ve Atan (2005) Türk bankacılık sistemi içinde faaliyet gösteren ticari bankaların etkinliğini veri zarflama analizi 
(VZA) ile ölçmüș ve bankaların sermaye yapılarındaki farklılașmanın bankaların etkinliklerinde farklılık yaratıp yaratmadığını değerlendirmiștir. Çalıșmada VZA ile hangi sermaye yapısındaki bankaların en etkin olduğu ve 2002 Aralık ile 2004 Eylül üçer aylık bilanço dönemleri itibariyle banka gruplarının aracilık etkinliğindeki değișim analiz edilmiștir. Ayrıca Tobit regresyon analizi ile VZA modelinde kullanılan girdi ve çıkłı değișkenlerinin bankaların etkinliğine katkısı belirlenmeye çalıșılmıștır.

Önal ve Sevimeser (2006) çalıșmalarında Türk bankacılık sektörünü sahiplik yapıları yönünden gruplandırarak etkinlik açısından incelemișlerdir. Bu amaçla çalıșmada banka grupları bazında 1980-2004 arası yıllara ait seçilmiș bilanço verileri üzerinde VZA yapılmıștır.

Özcan (2006) yılında çalıșmasında Türkiye'de faaliyet gösteren mevduat bankalarının teknik ve maliyet etkinlikleri analiz edilmiș ve aralarındaki farklar değerlendirilmiștir.

Özgür ve Eleren (2006) çalıșmalarında Türkiye'de mevcut yabancı sermayeli mevduat bankalarının etkinliklerinin ölçülmesi amacıyla ilgili bankaların bilanço ve gelir tablolarından belirli kalemlerle değerlendirilmek üzere girdi ve çıktı seti olușturulmuș ve VZA yöntemi uygulanarak yabancı sermayeli mevduat bankalarının etkinlik düzeyleri belirlenmeye çalıșılmıștır.

Șen (2006) çalıșmasında 1960-2004 dönemi itibari ile kamu ve özel bankaların erkinliklerini ölçmüș ve politik devresel dalgalanmaların Türk bankacilık sektörü üzerine etkilerini Tobit regresyon analizi ile incelemiștir.

Seyrek ve Ata (2010) Türk bankacılık sektöründe faaliyet gösteren mevduat bankalarının VZA ile etkinliklerini ölçmüșlerdir. Daha sonra bankaların etkinlik skorları kullanarak, etkinlik tahmininde önemli olan finansal performans göstergelerinin neler olduğunu veri madenciliği teknikleri kullanılarak tespit etmișlerdir.

Yapılan çalıșmalardan da görüleceği üzere genellikle bankaların etkinlikleri standart VZA yöntemi ile gerçekleștirilmiștir. Ancak, gelișen finansal piyasalar ile birlikte verimlilikte üretim yaklașımı düșünülecek olunursa, bankaların temel çıktıları olan portföy 
yatırımları ve krediler beraberinde kredi ve piyasa riski gibi bir takım riskleri de getirmektedir. ülkemizde banka etkinliği ölçümünde veya ölçüme risklerin etkisinin değerlendirilmesinde sınırlı sayıda çalıșma bulunmaktadır (örn: Ișık ve Hasan (2002), Özhan-Günay (2012), Eken ve Kale (2013)).

Standard VZA yönteminde bankaların belirli girdi ile istenilen çıktılarını arttırmadaki bașarıları değerlendirilmektedir. Ancak, belirtildiği üzere gerçekte ișletmelerde sürecin ișleyiși içerisinde istenilen ve istenilmeyen çıktılar aynı anda ortaya çıkmaktadır. İstenmeyen çıkıları da etkinlik değerlendirmelerinde dikkate alan birçok yöntem kullanılmaktadır. Bunlardan en çok bilinen ve sık kullanılan Fare ve diğerleri (1989) tarafından geliștirilmiș performans endeksidir. Bir diğer çok kullanılan yöntem ise Chung ve diğerleri (1997) tarafından geliștirilen istenilen ve istenmeyen çıktıların birlikte oluștuğu durumu değerlendirmeye katan uzaklık yönlü fonksiyon yaklașımıdır.

Dünya uygulamalarına bakıldığında bankacılık sektörü için riskleri etkinlik tahmininde kullanan çalıșmalarda genellikle piyasa riski ölçümleri değerlendirmeye katılmaktadır. Örneğin, Cebenoyan ve diğerleri (2001), Berger ve DeYoung (1997), Chang (1999), Altunbaș ve Liu (2000) ve Hughes ve diğerleri (2001) çalıșmalarında banka etkinliklerinde piyasa riski değerlendirmesinde bulunmușlardır. Ancak piyasa riski ve kredi riskini banka etkinliği açısından değerlendirmeye katan, örnek olarak Chang ve Chiu (2006) ile Sun ve Chang (2011) çalıșmaları gibi, daha az sayıda çalıșma bulunmaktadır.

Bu çalıșmada, Chang ve Chiu (2006) çalıșmasında değerlendirildiği gibi bankaların temel çıktıları olan portföy yatırımları ve krediler beraberinde kredi ve piyasa riski gibi bir takım riskleri de beraberinde getirir yaklașımı kullanılarak Türkiye'de faaliyet gösteren ticari bankaların etkinliklerinin uzaklık yönlü fonksiyon kriteri ile değerlendirilmesi amaçlanmıștır.

Bu çalıșma dört ana bölümden olușmaktadır. Birinci bölüm çalıșmanın amacını açıklayan ve literatür ile ilgili bilgi veren giriș bölümünden olușmaktadır. İkinci bölümde Uzaklık Yönlü Fonksiyon Yaklașımı ile ilgili detaylı bilgi verilmiștir. Üçüncü bölüm veri 
ile uygulama sonuçlarını özetlemektedir. Dördüncü bölüm çalıșmayı sonuçlandırmaktadır.

\section{Yöntem}

Herhangi bir hizmet veya ürün üreten bir ișletmenin etkin olarak çalıșıp çalıșmadığı ile ilgili olarak literatürde birçok çalıșma bulunmaktadır. Bu çalıșmalarda genellikle etkinlik ölçümünde "veri zarflama analizi (VZA)" yöntemi kullanmaktadır. VZA etkinliği ölçülen birimler arasında belirli bir girdi düzeyinde en çok çıkıyı üreten veya belirli bir çıkı düzeyi için an az girdiyi kullanan birimler etkin kabul edilmektedir (Coelli, 1996). Ancak, gerçekte ișletmelerde sürecin ișleyiși içerisinde istenilen ve istenmeyen çıktılar aynı anda ortaya çıkmaktadır. Bu durumda, etkinlik ölçümünde bu iki tip çıkının aynı anda değerlendirilmesi daha uygun olacaktır. Ancak, standard veri zarflama analizinde girdiler ile istenilen çıkılar değerlendirilmektedir. Bu nedenle, her iki çıktıyı etkinlik için değerlendirmeye katan birçok yeni çalıșma bulunmaktadır.

İstenilen ve istenmeyen çıkııı aynı anda değerlendiren çaIıșmalardan bilini Fare ve diğerleri (1989) tarafından geliștirilmiș performans endeksidir. Bu çalıșmada, geliștirilen performans endeksi yardımı ile istenilen ve istenmeyen çıktılar ayrıștırılarak etkinliğin ölçülebileceği belirtilmektedir. Burada istenilen çıktıların etkin sınır içerisinde belirli bir oranda artırılması hedeflenmekte olup, istenilmeyen çıktıların azaltılması da buna bağlı olarak değerlendirilmektedir. Sonuç olarak etkinlik puanlarının istenmeyen çıktıya çok duyarlı olduğu görüșüne ulașılmıștır.

Bir diğer yöntem ise 1997 yılında Chung ve diğerleri tarafından geliștirilmiș olan uzaklık yönlü fonksiyon yaklașımıdır. Bu çalıșmada, etkinlik ölçümünde bankacıllı sektörünün temel çıktıları olan portföy yatırımları ve kredilerinin aynı zamanda istenmeyen çıkılar olan kredi ve piyasa risklerini beraberinde getirdiği düșüncesi ile uzaklık yönlü fonksiyon kullanılması uygun görülmüștür.

\subsection{Uzaklık Yönlü Fonksiyon}

Chung ve diğerleri (1997) tarafından geliștirilen uzaklık yönlü fonksiyon yaklașımında ișletmeleri değerlendirilirken istenilen 
çıkıların arttırılması ve istenmeyen çıkıların ise azaltılmasına dayanan ölçüt kullanılmaktadır. Bu yaklașımda, istenilen çıktılar ile istenmeyen çıktıların aynı anda üretilmesi, ortaya çıkan bu istenmeyen çıkıının masraflı olacağı belirtilmektedir.

$y \in R^{M} M$ tane istenilen çıktıyı, $b \in R^{I}$ I tane istenmeyen çıktıyı ve $x \in R^{N}$ ise $\mathrm{N}$ adet girdi değerleri ifade edecek olursa, çıktılar cinsinden ifade edilen üretim Eșitlik 1'deki gibi tanımlanıyor olsun:

$$
P(x)=\{(y, b): x \text { üretir }(y, b)\}
$$

Burada istenilmeyen çıktıların masraflı olması (elden çıkarılabilirliği düșük) așağıdaki gibi modellenmektedir.

$$
(y, b) \in P(x) \text { ve } 0 \leq \mathrm{q} \leq 1 \text { gerektirir }(\mathbf{q} y, \mathbf{q} b) \in P(x)
$$

Bu ayn zamanda, girdiler sabit iken istenmeyen girdilerin azaltılması ancak istenen girdilerin artırılması durumunda uygun çözüm alanı içerisinde olması anlamına gelmektedir.

Bu modelde aynı zamanda istenilen girdilerin serbestçe elden çıkarılabilir olduğu varsayımı Eșitlik 3'deki gibi, istenilen ve istenmeyen çıktıların birlikte üretiliyor olması ise Eșitlik 4 'deki gibi ifade edilmektedir.

$$
(y, b) \in P(x) \text { ve } y^{\prime} \leq y \text { gerektirir }\left(y^{\prime}, b\right) \in P(x)
$$

Eğer $(y, b) \in P(x)$ ise ve $b=0$ ise $y=0$ 'dır.

Bu durumda, pozitif bir istenilen çıkının olması durumunda aynı zamanda pozitif bir istenmeyen çıktı olması durumu da söz konusudur. Bu çalıșmada, istenmeyen çıktılarını azaltan șirketlere iyi performans verebilmek için Eșitlik 5'de verilen uzaklık yönlü fonksiyon teknolojik etkinlik için kullanılmıștır.

$$
\vec{D}_{0}(x, y, b ; g)=\sup \{\mathrm{b}:(y, b)+\mathrm{b} g \in P(x)\}
$$

Burada, $g$ çıktıları ölçeklendiren yön vektörüdür. Bu çalıșmada $g=(y,-b)$ olarak kullanılmaktadır. Bu durumda, Chung ve diğerleri (1997)'ne göre VZA doğrusallığı korunmakła ve uzaklık yönlü fonksiyon așağıda verilen doğrusal programlama modeli ile elde edilmektedir. 


$$
\begin{aligned}
\vec{D}_{0}^{t} & \left(x^{t, k}, y^{t, k}, b^{t, k} ; g=\left(y^{t, k},-b^{t, k}\right)\right)=\text { Enbb } \\
\text { s.t. } & \sum_{k=1}^{K} z_{k} y_{k, m}^{t} \geq(1+\mathrm{b}) y_{k, m}^{t}, m=1, \ldots, M \\
& \sum_{k=1}^{K} z_{k} b_{k, i}^{t} \geq(1-\mathrm{b}) b_{k, i}^{t}, i=1, \ldots, I \\
& \sum_{k=1}^{K} z_{k} x_{k, n}^{t} \geq(1-\mathrm{b}) x_{k, n}^{t}, n=1, \ldots, N \\
& z_{k} \geq 0, k=1, \ldots, K
\end{aligned}
$$

Burada z yoğunluk değișkenidir. Sonuçta elde edilen beta değeri karar birimlerinin etkin olmama skorlarını göstermektedir. Beta değerleri sıfır olarak elde edilen karar birimleri, VZA tersi olarak etkin kabul edilmektedir.

\section{Uygulama}

\subsection{Veri}

Çalıșmada kullanılan veriler belirlenirken, öncelikle veri setini olușturan bankaların kendi aralarında homojen olmasına dikkat edilmiștir. Bu çerçevede, 2013 yıl sonu itibariyle Türk Bankacılık Sektörü'nde faaliyette bulunan 45 adet bankadan, 23 adedinin verileri çalıșma kapsamına alınmıșıı. Söz konusu 23 banka, mevduat bankası olup, aynı zamanda çok șubeli banka niteliğindedir. Calıșma kapsamına alınan bankaların toplam büyüklüğü Türk Bankacılık Sektörü'nün \% 93'ünü olușturmaktadır.

2000 Kasım 2001 Șubat krizleri sonrasında yeniden yapılandırma çalıșmalarının sürdüğü dönemler ile yabancı sermayenin yoğun ilgisinin olduğu 2004-2005 yılları dikkate alınarak, çalıșma kapsamındaki verilerin 2006 yılından itibaren olușturulması uygun görülmüștür.

Toplam 23 bankanın çalıșmada kullanılan bilanço verilerinden, kredi, mevduat, menkul kıymetler portföyü, aktif toplamı ile çalıșan sayıları Türkiye Bankalar Birliğiınin İstatistiki Veriler ${ }^{3}$ platformundan elde edilmiștir. Kredi ve piyasa riski verileri ise her bir

3 https://www.tbb.org.tr/tr/banka-ve-sektor-bilgileri/istatistiki-raporlar. 
bankanın yıl sonlarına ait bağımsız denetim raporlarından derlenmiștir. Bu kapsamda temin edilen 1.288 adet veri ile analiz gerçekleștirilmiștir.

\subsection{Uygulama Sonuçları}

Bankacılıkta etkinlik ölçümünde girdi ve çıkıların nelerden olușacağı konusunda literatürde henüz görüș birliğine varılmamıștır (Seyrek ve Ata, 2010). Girdi ve çıkıların belirlenmesi ile ilgili üretim, aracilık ve karlılık yaklașımları ortaya atılmıștır. Gelișen finansal piyasalar ile birlikte bankaların temel çıkıları olan portföy yatırımları ve krediler beraberinde kredi ve piyasa riski gibi bir takım riskleri de getirmektedir. Bu yaklașım göz önünde bulundurularak ve Chang ve Chiu (2006) çalıșması temel alınarak, bu çalıșmada bankaların personel sayıları, toplam aktifleri ve mevduat miktarları temel üç girdi olarak değerlendirilmiș, kredileri ve porfföy yatırımları istenilen çıktılar ve kredi riskleri ile piyasa riski değerlerinin ise istenilmeyen çıktılar olarak kullanılmaları uygun görülmüștür.

Öncelikle veri seti içerisinde bulunan 23 banka için 20062013 yılları ayrı ayrı değerlendirilerek her bankanın istenmeyen çıkı olan kredi ve piyasa risklerini değerlendirmeye katarak ve katmayarak performans ölçümünde kullanılan uzaklık fonksiyon değerleri bulunmuș ve Tablo 1'de özetlenmiștir.

Tablol'de koyu renk ile ișaretli olan fonksiyon değerleri etkin olan bankalara ilișkin değerleri göstermektedir. Riskleri dikkate alarak ve almayarak değerlendirildiği durumun her ikisinde de etkin olan bankalar ise çerçeve içerisine alınmıștır. Daha öncede belirtildiği üzere uzaklık fonksiyon değeri etkin olmama kriteri olarak bilinmektedir ve fonksiyon değeri ne kadar küçükse etkinlik o kadar yüksektir. Literatüre göre etkin olan birimlerin uzaklık fonksiyonlarının 0 olması gerekmektedir.

Tablol'den görüleceği üzere bankaların riskleri etkinlik ölçümüne dahil edilerek ve edilmeyerek hesaplanan uzaklık fonksiyon değerleri farklılık göstermektedir. Bazı bankalar riskleri dikkate alınmadan, yalnızca girdileri ve istenilen çıktıları dikkate alınarak değerlendirildiklerinde etkin olarak bulunmamalarına rağmen, 
kredi ve portföylerini arttırmaya çalıșırken aynı zamanda kredi ve piyasa risklerini ise azaltmayı veya bașka bir deyișle kontrol altında tutmayı bașardıkları için aslında etkin olarak kabul edilmișlerdir. Bu durumun tersi olarak bazı yıllarda bazı bankalar riskleri dikkate alarak bakıldığında etkin olmadıkları halde, riskleri dikkate alınmayarak değerlendirildiklerinde etkin bulunmușlardır. Bu durum değerlendirildiğinde, o bankaların o dönemde portföy değerleri ile kredi değerleri yüksek iken, aynı zamanda piyasa ve özellikle kredi riskinin yüksek olduğu gözlemlenmiștir. Risklerdeki artıș, etkin olmama kriteri olan uzaklık fonksiyonunda da artıșa sebep olmuștur. Örneğin, Banka 12'nin 2010 yılında portföy ve kredi değerlerinde artıș olduğu aynı zamanda özellikle kredi riskinin de 2010 döneminde yüksek olduğu gözlemlenmiștir. 


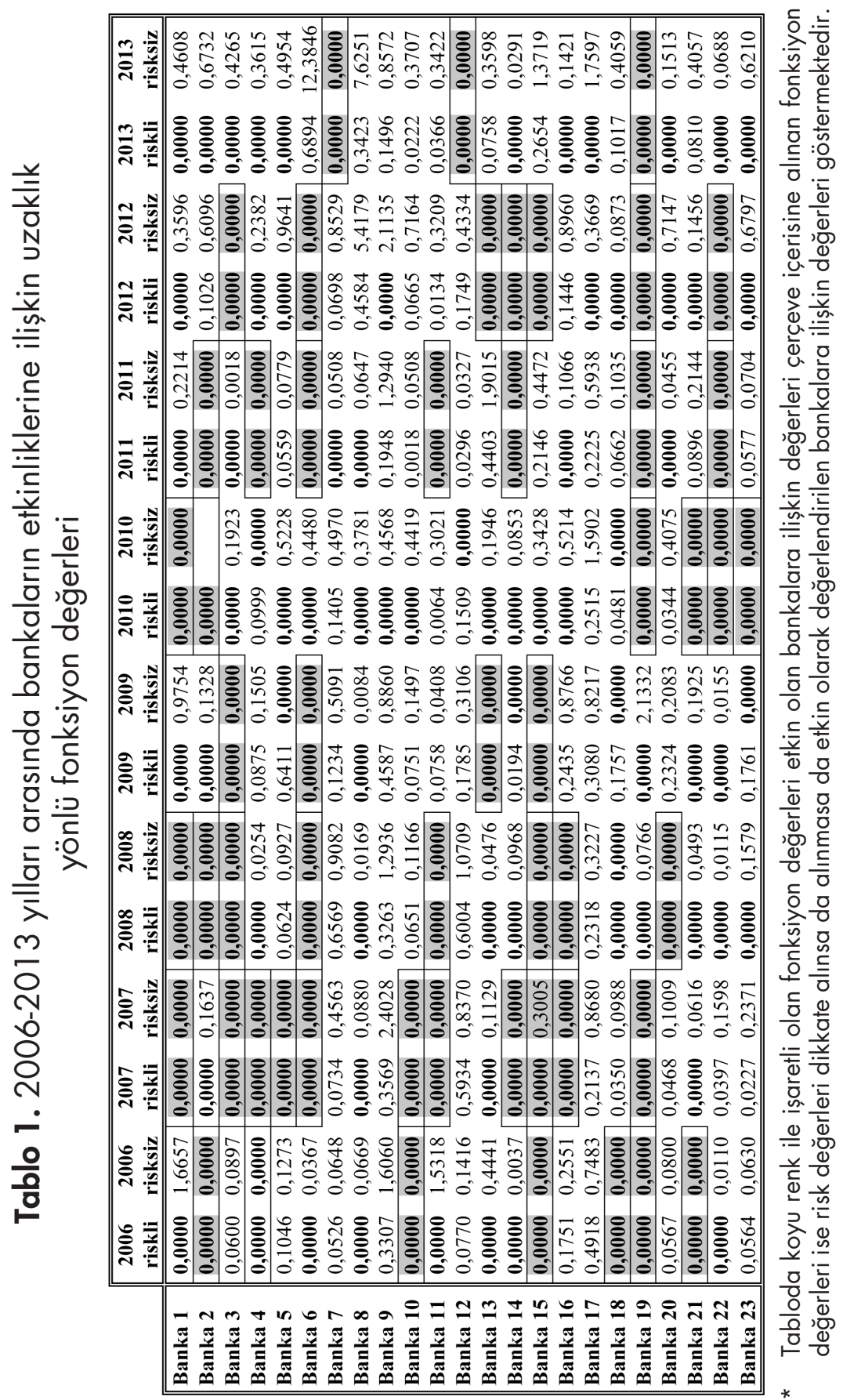


Her yıl için bankaların etkinlikleri değerlendirildikten sonra riskli ve risksiz hesaplanan uzaklık fonksiyon değerlerinde anlamlı bir fark olup olmadığı parametrik olmayan Mann-Whitney $U$ testi ile test edilmiș ve sonuçlar Tablo 2 'de verilmiștir. Mann-Whitney $U$ testi niceliksel ölçekli gözlemleri verilen iki örneklemin aynı dağılımdan gelip gelmediğini incelemek için kullanılan bir parametrik olmayan istatistik testtir. Mann-Whitney testinde sifir hipotezi, veri olan iki örneklemin aynı dağılımdan geldiği șeklinde kurulmaktadır.

Tablo 2. 2006-2013 yılları arasında uzaklık yönlü fonksiyon değerlerindeki farklara ilișkin Mann-Whitney $U$ testi sonuçları

\begin{tabular}{|l|c|c|c|c|c|c|c|c|}
\hline & yil2006 & yil2007 & yil2008 & yil2009 & yil2010 & yil201 1 & yil2012 & yil2013 \\
\hline $\begin{array}{l}\text { Mann- } \\
\text { Whitney U }\end{array}$ & 171,000 & 182,000 & 183,500 & 219,000 & 141,000 & 186,500 & 116,000 & 82,000 \\
$\begin{array}{l}\text { Wilcoxon } \\
\text { W }\end{array}$ & 447,000 & 458,000 & 459,500 & 495,000 & 417,000 & 462,500 & 392,000 & 358,000 \\
Z & $-2,159$ & $-1,978$ & $-1,966$ & $-1,031$ & $-2,961$ & $-1,789$ & $-3,487$ & $-4,114$ \\
$\begin{array}{l}\text { P-Sig. } \\
\text { (2-tailed) }\end{array}$ &, 031 &, 048 &, 049 &, 303 &, 003 &, 074 &, 000 &, 000 \\
\hline
\end{tabular}

Tablo 2'den görüleceği üzere \%90 güvenilirlikle tabloda verilen $P$ değerleri 2009 yılı haricinde hep $\alpha=0$, lanlamlılık düzeyinden küçük olduğu için sıfır hipotezi red edilmektedir. Eğer, test \%95 güvenilirlikle yapılırsa 2009 ve 2011 yılları haricinde sıfır hipotezi red edilmektedir. Bu durumda, 2009 ve 2011 yılları haricinde her yılda riskli ve risksiz fonksiyon değerleri arasında anlamlı farklılıklar gözlemlenmiștir. Bu durumda, riskleri dikkate almadan yalnızca girdileri ve istenilen çıktıları dikkate alarak değerlendirme yapmanın yanılıcı olacağı sonucuna ulașılmıștır.

Yıllar itibari ile bankalar değerlendirildiğinde bankaların etkin olup olmadıkları o yılın finansal ve ekonomik koșullarına ve yıllar itibari ile bankaların ișleyiș ile ilgili yaptığı değișikliklere, bankaların yatıım ve risk stratejilerinde yaptıkları değișikliklere göre değișim göstermektedir. Bu nedenle, son olarak girdi ve çıkı değerlerinin yıllar itibari ile ortalamaları alınarak riskli ve risksiz olarak uzaklık fonksiyonu değerleri hesaplanmıs ve yine ortalamalar için hesaplanan riskli ve risksiz uzaklık fonksiyon değerleri arasında anlamlı bir fark olup olmadığı parametrik olmayan 
Mann-Whitney $U$ testi ile test edilmiștir. Sonuçlar, Tablo 3 ve Tablo $4^{\prime}$ de verilmiștir.

Tablo 3. Girdi ve çıktı değerlerinin 2006-2013 yılları ortalaması alınarak değerlendirme yapıldığı bankaların etkinliklerine ilișkin uzaklık yönlü fonksiyon değerleri

\begin{tabular}{|c|c|c|}
\hline & Ortalama Riskli & Ortalama Risksiz \\
\hline Banka 1 & 0,0000 & 0,7043 \\
\hline Banka 2 & 0,0000 & 0,1842 \\
\hline Banka 3 & 0,0000 & 0,0000 \\
\hline Banka 4 & 0,0000 & 0,0378 \\
\hline Banka 5 & 0,0000 & 0,0054 \\
\hline Banka 6 & 0,0000 & 0,0603 \\
\hline Banka 7 & 0,0548 & 0,2464 \\
\hline Banka 8 & 0,0320 & 0,0389 \\
\hline Banka 9 & 0,0000 & 1,1644 \\
\hline Banka 10 & 0,0000 & 0,1257 \\
\hline Banka 11 & 0,0000 & 0,0000 \\
\hline Banka 12 & 0,0556 & 0,1830 \\
\hline Banka 13 & 0,0000 & 0,0242 \\
\hline Banka 14 & 0,0000 & 0,0000 \\
\hline Banka 15 & 0,0000 & 0,0000 \\
\hline Banka 16 & 0,0000 & 0,3184 \\
\hline Banka 17 & 0,2500 & 1,1440 \\
\hline Banka 18 & 0,0166 & 0,0937 \\
\hline Banka 19 & 0,0000 & 0,0000 \\
\hline Banka 20 & 0,0000 & 0,1191 \\
\hline Banka 21 & 0,0000 & 0,1469 \\
\hline Banka 22 & 0,0000 & 0,0000 \\
\hline Banka 23 & 0,0000 & 0,1347 \\
\hline
\end{tabular}

Tablo 3'de yine koyu renk ile ișaretli olan fonksiyon değerleri etkin olan bankalara ilișkin değerleri, çerçeve içerisine alınan fonksiyon değerleri ise risk değerleri dikkate alınsa da alınmasa 
da etkin olarak değerlendirilen bankalara ilișkin değerleri göstermektedir.

Tablo 3 sonuçları değerlendirildiğinde, yıllar itibari ile genellikle etkin bulunan bankaların ortalama değerler üzerinden değerlendirildiklerinde de etkin çalıștıkları sonucuna ulașılmıștır. Ortalamalar üzerinden bakıldığında riskleri dikkate almadan etkin olmadığı sonucuna varılan bazı bankaların, riskler dikkate alındığında etkin çalıștıkları sonucuna ulașılmıștır.

Tablo 4. 2006-2013 yılları ortalaması ile hesaplanan uzaklık yönlü fonksiyon değerlerindeki farklara ilișkin Mann-Whitney U testi sonuçları

\begin{tabular}{|l|r|}
\hline & \multicolumn{1}{|c|}{ Ortalama } \\
\hline Mann-Whitney U & 108,000 \\
Wilcoxon W & 384,000 \\
Z & $-3,711$ \\
Asymp. Sig. (2-tailed) &, 000 \\
\hline
\end{tabular}

Tablo 4' de verilen Mann-Whitney $U$ testi incelendiğinde verilen $\mathrm{P}=0,000$ değeri \%95 güvenilirlikle $\alpha=0,05$ değerinden küçük olduğu için sıfır hipotezi red edilmektedir. Bu sonuç ise bize yıllar ortalaması dikkate alınarak hesaplanan riskli ve riskiz uzaklık fonksiyon değerleri arasında anlamlı farklılıklar olduğunu göstermektedir.

\section{Sonuç ve Öneriler}

Türk Bankacılık Sektörü, ülke ekonomisinin öncü sektörü konumundadır. Bu kapsamda sektörün etkin ve verimli çalıșması, ekonominin dinamikleri açısından büyük önem tașımaktadır. Kaynakların yetersiz olduğu ülkemizde, etkin kaynak kullanımın önemi bir kat daha artmaktadır. Ancak, gerek rekabet artıșı, gerekse finansal ürünlerin çeșitliliğindeki artıșlar çeșitli riskleri de beraberinde getirmiștir. Bu çerçevede etkinlik kavramı kapsamına risk yönetimi de alarak, riskleri iyi yöneterek kaynakların etkin kullanımı șekline dönüșmüștür. 
Bu bakıș açısından yola çıkarak, ülkemizde bankacılık sektörü için bugüne kadar yapılan etkinlik çalıșmalarında yer almadığı görülen risk kavramının da dahil edileceği bir analiz yapılması düșüncesinden hareket edilmiștir. Çünkü, bankacilık sektöründe faaliyetler özü gereği çeșitli riskleri de beraberinde getirmektedir. Bir bankanın rakiplerine göre sadece az kaynakla aynı çıktıyı sağlamıș olmasının yeterli olmayacağı, riskleri yöneterek az kaynakla aynı çıktıyı sağlamıș olmasının gerçek performans kriteri olarak değerlendirilmesinin daha doğru olacağı düșünülmektedir.

Türk Bankacılık Sektöründe faaliyette bulunan 23 bankanın çeșitli verileri ile yapılan risk bazlı etkinlik değerlendirmesi sonuçlarına göre elde edilen temel bulgular șöyledir:

* Etkinlik değerlendirmesinde risk gözardı edilerek ve risk dikkate alınarak yapılan analizlerde analizin yapıldığı 20062013 arasından 8 dönem için özet tablo așağıdadır:

Tablo 5. Etkinlik sonuçlarının 2006-2013 dönemleri için risk dikkate alınarak ve alınmayarak sonuçları ve farklılașması

\begin{tabular}{|l|c|c|c|}
\hline & Toplam Dönem Sayısı & Örtüșen Dönem Sayısı & Farklı Dönem Sayısı \\
\hline Banka 1 & 8 & 3 & 5 \\
\hline Banka 2 & 8 & 4 & 4 \\
\hline Banka 3 & 8 & 4 & 4 \\
\hline Banka 4 & 8 & 3 & 5 \\
\hline Banka 5 & 8 & 1 & 7 \\
\hline Banka 6 & 8 & 5 & 3 \\
\hline Banka 7 & 8 & 1 & 7 \\
\hline Banka 8 & 8 & 0 & 8 \\
\hline Banka 9 & 8 & 0 & 8 \\
\hline Banka 10 & 8 & 2 & 6 \\
\hline Banka 11 & 8 & 3 & 5 \\
\hline Banka 12 & 8 & 1 & 7 \\
\hline Banka 13 & 8 & 2 & 6 \\
\hline Banka 14 & 8 & 3 & 3 \\
\hline Banka 15 & 8 & 5 & 5 \\
\hline
\end{tabular}




\begin{tabular}{|l|l|l|l|}
\hline Banka 16 & 8 & 2 & 6 \\
\hline Banka 17 & 8 & 0 & 8 \\
\hline Banka 18 & 8 & 1 & 7 \\
\hline Banka 19 & 8 & 6 & 2 \\
\hline Banka 20 & 8 & 1 & 7 \\
\hline Banka 21 & 8 & 2 & 6 \\
\hline Banka 22 & 8 & 3 & 5 \\
\hline Banka 23 & 8 & 1 & 7 \\
\hline
\end{tabular}

Tablo 5'den görüleceği üzere toplam 23 bankanın etkinlik analizi sonuçları risk dikkate alınarak ve alınmayarak karșılaștırıldığında, 8 dönemin tamamında aynı sonucu veren banka olmadığı görülmektedir. 7 dönem için de benzer sonuç sözkonusudur. 6 dönemde benzer sonuç sağlayan 1 banka, 5 dönemde 2 banka, 4 dönemde 2 banka, 3 dönemde 5 banka, 2 dönemde 4 banka, 1 dönemde 6 banka ve hiç örtüșme sağlamayan 3 banka olduğu görülmüștür.

* Risk dikkate alınarak ve risk dikkate alınmadan yapılan etkinlik analizlerinde benzer sonuç veren bankalar ile farklı sonuca ulașılan bankaların ölçek açısından homojen olmadığı görülmektedir. Bu kapsamda, büyük ölçekli bankalarda hem benzer hem de farklı sonuçlara ulașılırken, aynı șekilde orta ve küçük ölçekli bankalarda da kendi aralarında bir benzerlik olmadığı görülmektedir. Dolayısı ile ölçek büyüklüğünün sonuçların örtüșmesi ya da ayrıșması konusunda etkili olmadığı düșünülmektedir.

* Tüm dönemlerin ortalaması üzerinden aynı analiz yapıldığında ise Tablo 3 de detayları yer aldığı üzere 23 bankada risk dikkate alınarak ve alınmayarak etkinlik analizinin sonuçları 6 bankada değișmemekte, 12 bankada risk dikkate alınmadığı durumda etkin görünmeyen sonuçlar, risk dikkate alındığında etkin olduğu bilgisini vermektedir. 5 bankada ise risk dikkate alındığı ve alınmadığı durumların ikisinde de etkinlik seviyesi olumsuz çıkmaktadır.

* Yapılan analizlere göre, etkinlik değerlendirmesinde daha gerçekçi sonuçlara ulașmak ve daha doğru kararlar alabilmek açı- 
sından risk faktörünün de temel veri olarak dikkate alınmasının gerektiği söylenebilir.

Bu kapsamda, bankaların verimli çalıșıp çalıșmadıklarını değerlendirirken yalnızca olumlu olan çıkılar ile bankaları değerlendirmenin yanıltıcı olacağı, bu nedenle risk seviyelerini nasıl yönettiklerinin de dikkate alınması gerektiği, riske ilișkin verilerin de analizlerde kullanılmasının uygun olacağı sonucuna ulașılmıștır.

\section{KAYNAKCุA}

Altunbas, Y., M. H. Liu, P. Molyneux and R. Seth. 2000. Efficiency and risk in Japanese banking. Journal of Banking and Finance. 24, 1605-1628.

Berger, A. N. and R. DeYoung. 1997. Problem loans and cost efficiency in commercial banks. Journal of Banking and Finance. 21, 849-870.

Cebenoyan, A. S., E. S. Cooperman and C. A. Register. 1993. Firm efficiency and the regulatory closure of S\&Ls: An empirical investigation. Review of Economics and Statistic. 75, 540-545.

Chang, C. C. 1999. The nonparametric risk-adjusted efficiency measurement: An application to Taiwan's major rural financial intermediaries. American Journal of Agricultural Economics. 81, 902-913.

Chang T.C. and Y. H. Chiu. 2006. Affecting factors on risk-adjusted efficiency in Taiwan's banking Industry. Contemporary Economic Policy. 24 (4), 634648.

Chung Y. H., R. Fare and S. Grosskopf. 1997. Productivity and undesirable outputs: A directional distance function approach. Journal of Environmental Management. 51, 229-240.

Cingi, S. ve A. Tarım. 2000. Türk banka sisteminde performans ölçümü VZA - Malmquist TFP endeksi uygulaması. Türkiye Bankalar Birliği Araștırma Tebliğleri Serisi. 1, 1-34.

Coelli, T.J. 1996. A guide to VZAP version 2.1: A data envelopment analysis program. Centre For Efficiency and Productivity Analysis (CEPA) Working Papers, The University of New England, 8/9, 61-50.

Çatalbaș, G. K. ve M. Atan. 2005. Bankacilıkła etkinlik ve sermaye yapısının bankaların etkinliğine etkisi. Iktisat Isletme ve Finans. 20(237), 49-62.

Eken M. H. and S. Kale. 2013. Evaluating the efficiency of Turkish banks: A risk and profitability approach. JCC: The Business and Economics Research Journal. 6(1), 53-68. 
Ekren, N. ve F. Emiral. 2002. Türk bankacilık sisteminde etkinlik analizi (veri zarflama analizi uygulaması). Active Bankacılık ve Finans Dergisi. 24(4), $1-32$.

Fare, R., S. Grosskopf and C. Pasurka. 1989. The e $\square$ ects of environmental regulation on the e $\square$ ciency of electric utilities. Applied Economics. 21, 225235.

Hughes, J. P., L. J. Mester and C. G. Moon. 2001. Are scale economies in banking elusive or illusive? Evidence obtained by incorporating capital structure and risk-taking into models of bank production. Journal of Banking and Finance. 25, $2169-2208$.

Isik, I. and M. K. Hassan. 2002. Technical, scale and allocative efficiencies of Turkish banking Industry. Journal of Banking and Finance. 26, 719-766.

Önal Y. B. ve C. Sevimeser. 2006. Yabancı banka girișlerinin Türk bankacılık sistemine etkileri: yerli ve yabancı bankaların etkinlik analizi. C..Ü. Sosyal Bilimler Enstitüsü Dergisi. 15(2), 295-312.

Özcan A. 2010. Türkiye'de mevduat bankalarının teknik ve maliyet etkinliği (2003-2007). Finans Politik \& Ekonomik Yorumlar. 47(544), 47-62.

Özgür, E. ve A. Eleren. (2006). Türkiye'de yabancı sermayeli yerli mevduat bankalarının veri zarflama yöntemi ile etkinlik analizlerinin yapılması. Afyon Kocatepe Üniversitesi İ.i. B.F Dergisi. 8(2), 53-76.

Özkan-Günay E. N. 2012. Risk incorporation and efficiency in emerging market banks during the global crisis: Evidence from Turkey, 2002-2009. Emerging Markets Finance and Trade. 48(5), 91-102.

Seyrek, I. H. ve H. A. Ata. 2010. Veri zarflama analizi ve veri madenciliği ile mevduat bankalarında etkinlik ölçümü. BDDK Bankacılık ve Finansal Piyasalar. 4(2), 67-84.

Sun L. and T.C. Chang. 2011. A comprehensive analysis of the effects of risk measures on bank efficiency: Evidence from emerging Asian countries. Journal of Banking and Finance. 35, 1727-1735.

Șen, S. A. 2006. Bankacılık sektörü ve devlet müdahaleleri: politik devresel dalgalanmalar çerçevesinde Türk bankacılık sektörü etkinlik analizi. Sosyoekonomi. 2, 11-30.

https://www.tbb.org.tr 
